\title{
\begin{tabular}{l|l} 
Mibraries & DSpace@MIT
\end{tabular}
}

\author{
MIT Open Access Articles
}

Future Climate Scenarios for the Indus Basin

The MIT Faculty has made this article openly available. Please share how this access benefits you. Your story matters.

Citation: Yu, Winston, Yi-Chen Yang, Andre Savitsky, Donald Alford, Casey Brown, James Wescoat, Dario Debowicz, and Sherman Robinson. "Future Climate Scenarios for the Indus Basin." The Impacts of Climate Risks on Water and Agriculture (April 18, 2013): 77-93. () International Bank for Reconstruction and Development/The World Bank

As Published: http://dx.doi.org/10.1596/9780821398746_CHO4

Publisher: The World Bank

Persistent URL: http://hdl.handle.net/1721.1/90256

Version: Final published version: final published article, as it appeared in a journal, conference proceedings, or other formally published context

Terms of use: Creative Commons Attribution 


\section{Future Climate Scenarios for the Indus Basin}

\section{Key Messages}

- Historical trends show (statistically significant) increasing temperatures and annual precipitation over the last century over the entire country of Pakistan.

- Each river in the Indus has its own hydrologic regime and timing depending on the mix of snow, ice, and monsoon contributions.

- Historically, the annual flows into Tarbela reservoir have been decreasing over time.

- The general findings from a wide range of general circulation model (GCM) outputs show agreement among models regarding continued increases in temperature into the future. Increases are estimated to be at worst close to $3^{\circ} \mathrm{C}$ warmer by the 2050s. These models are likely more reliable for the irrigated plains than the mountainous upper basin.

- There is not agreement among models regarding changes in precipitation (both in magnitude and direction) because standard errors are large.

- However, there is some indication of a general trend in increased precipitation during the summer and a decrease during the winter. These changes appear to be more pronounced in the southern parts of the country.

- Using the snow and ice hydrology model developed in the previous chapter and a wide range of climate futures, the postulated impact of climate change on inter-annual flow variations is generally comparable with the current interannual variations.

- The primary impact on the Upper Indus Basin (UIB) of all but the most extreme climate change scenarios could be a shift in the timing of peak runoff and not a major change in annual volume.

- The review of GCM outputs supports the subsequent modeling approach where ranges of climate risks are informed by GCM outputs but not driven directly by them. 
Floods and droughts of the past decade have increased concerns about climate change in the Indus Basin. Analysis of climate variability and change has advanced considerably since the last assessment of potential climate impacts in the Indus Basin 20 years ago (Wescoat and Leichenko 1992). The most comprehensive assessments of climate change risks in Pakistan to date are from the Global Change Impact Study Centre (GCISC) (Ali, Hasson and Khan 2009; Faisal et al. 2009; Iqbal et al. 2009a, 2009b, 2009c; Islam et al. 2009a, 2009b, 2009c; Saeed et al. 2009a, 2009b, 2009c; Saeed, Sheikh, and Khan 2009d; Sheikh et al. 2009; Syed et al. 2009). This chapter will review this work. The climate scenarios described here will be used in subsequent modeling chapters. It is important to underscore that for modeling purposes the Upper and Lower Indus Basin require different hydroclimatic approaches, thus they are treated separately in the following sections.

\section{Overview of Historical Patterns and Trends}

Pakistan experiences some of the hottest and driest conditions in the South Asia region, with the exception of the UIB where cool, moist conditions prevail. The upper basin and northern plains lie on the western edge of the monsoon and have comparatively high winter precipitation. The temperature trends for the country as a whole, using Climatic Research Unit (CRU) gridded data, indicate an overall pattern of warming $\left(+0.6^{\circ} \mathrm{C}\right)$ over the past century (Sheikh et al. 2009) (figure 4.1). This trend is significant at the 99 percent level. These temperature trends do not display a consistent regional pattern. Annual warming has occurred over the past half-century in the Upper Indus, Punjab plains, and the Balochistan plateau, while some cooling has occurred in the lower parts of the Indus. Examined by season, the patterns are even more complex, as cooler monsoons and hotter summers (April-May) are observed over most of the basin. These variations offset one another in annual temperature trends, which are generally less than $1^{\circ} \mathrm{C}$, except in Balochistan and the Western Highlands. Overall seasonal warming and

Figure 4.1 CRU Mean Temperature Data for Pakistan over the 20th Century

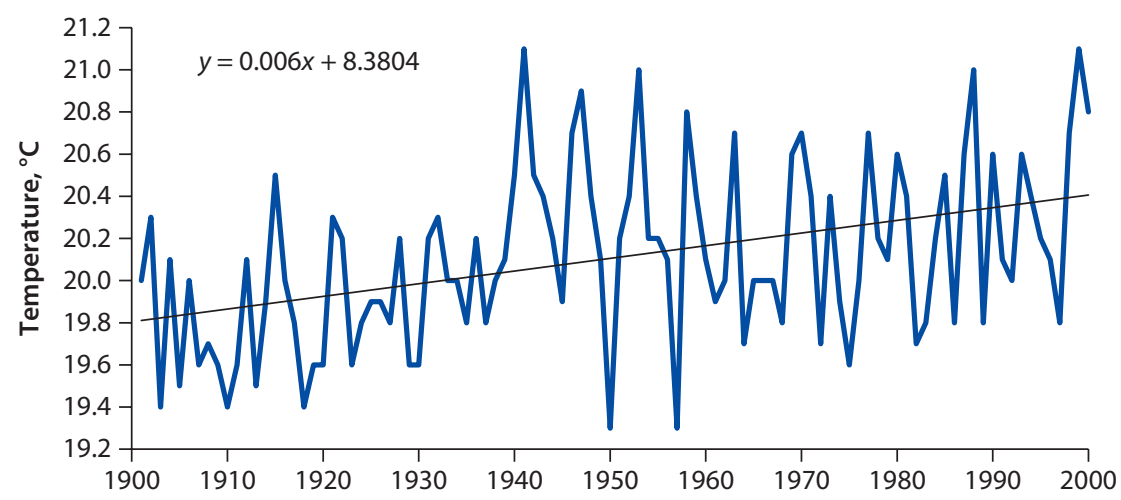

Source: Sheikh et al. 2009. 
cooling trends are somewhat higher, with changes ranging up to $1^{\circ} \mathrm{C}$. These patterns of mean temperature are further complicated by different trends in minimum and maximum temperatures in which maximum temperatures have increased over the Upper Indus and decreased over the irrigated basin, while minimum temperatures have decreased over the Upper Indus and Sindh but increased over Punjab and the coastal belt.

Precipitation trends over the country have also increased significantly over the past century. Figure 4.2 indicates a century-long increase of 25 percent, or $63 \mathrm{~mm}$, over the country during the 20th century. This trend is significant at the 99 percent level. Precipitation patterns across provinces and within the year are less clear.

This overall increasing trend in precipitation is apparent over most of the regions in the country. Table 4.1 shows the calculated annual and seasonal average precipitation (1951-2000) across the different regions. Increasing

Figure 4.2 CRU Precipitation Data over Pakistan over the 20th Century

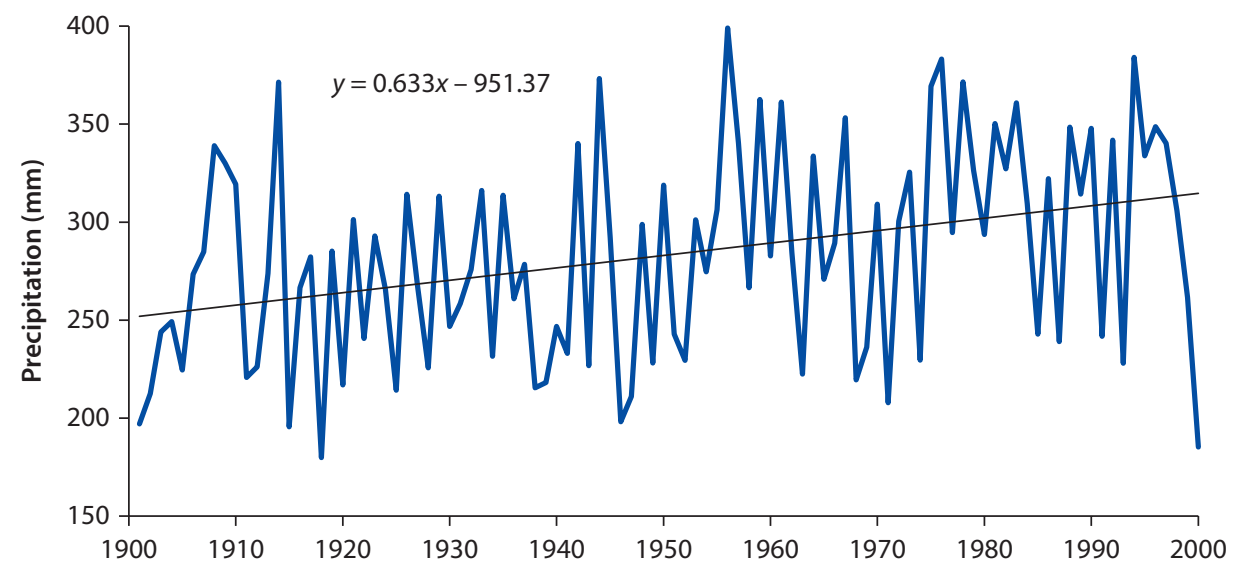

Source: Sheikh et al. 2009.

Table 4.1 Annual and Seasonal Average Precipitation by Zone, 1951-2000 millimeters

\begin{tabular}{lrrrrc}
\hline Region & $\begin{array}{c}\text { Annual } \\
\text { average }\end{array}$ & $\begin{array}{c}\text { Monsoon } \\
\text { average }\end{array}$ & $\begin{array}{c}\text { Winter } \\
\text { average }\end{array}$ & $\begin{array}{c}\text { Apr-May } \\
\text { average }\end{array}$ & $\begin{array}{c}\text { Oct-Nov } \\
\text { average }\end{array}$ \\
\hline Greater Himalayas (winter dominated) & 436.3 & 99.7 & 185.1 & 116.6 & 36.5 \\
Sub-mountain region (monsoon dominated) & 1272.9 & 710.4 & 352.2 & 146.1 & 68.2 \\
Western Highlands & 571.1 & 238.6 & 201.5 & 97.8 & 34.5 \\
Central and Southern Punjab & 286.9 & 189.1 & 54.7 & 32.1 & 10.8 \\
Lower Indus Plains & 148.7 & 120.4 & 15.1 & 6.3 & 5.0 \\
Balochistan Plateau (Northern) & 246.0 & 112.5 & 92.2 & 32.2 & 9.6 \\
Balochistan Plateau (Western) & 74.6 & 13.4 & 50.5 & 8.1 & 3.1 \\
Coastal Belt & 155.7 & 89.3 & 55.9 & 4.9 & 5.9 \\
\hline
\end{tabular}

Source: Sheikh et al. 2009. 
Table 4.2 Precipitation Trends, 1951-2000

millimeters

\begin{tabular}{lccc}
\hline Region & Annual & Monsoon (Jun-Sep) & Winter (Dec-Mar) \\
\hline Greater Himalayas (winter dominated) & 0.49 & 1.73 & -0.04 \\
Sub-mountain region (monsoon dominated) & 0.30 & 0.38 & 0.53 \\
Western Highlands & -0.02 & 0.22 & 0.00 \\
Central and Southern Punjab & 0.63 & 0.57 & 0.99 \\
Lower Indus Plains & 0.22 & 0.45 & -0.27 \\
Balochistan Plateau (Northern) & 1.19 & 1.16 & 1.14 \\
Balochistan Plateau (Western) & 0.10 & -0.20 & -0.40 \\
Coastal Belt & -0.82 & -1.34 & 0.00 \\
\hline
\end{tabular}

Source: Sheikh et al. 2009.

Table 4.3 Annual Stream Inflow, 1961-2010

million acre-feet

\begin{tabular}{lrc}
\hline River & Mean & Standard deviation \\
\hline Indus & 60.30 & 7.37 \\
Chenab & 25.48 & 4.03 \\
Jhelum & 22.08 & 4.70 \\
Kabul & 15.93 & 3.89 \\
Swat & 4.69 & 1.06 \\
Ravi & 4.13 & 2.83 \\
Sutlej & 2.59 & 2.99 \\
Soan & 1.07 & 0.47 \\
Harro & 0.73 & 0.54 \\
Total & 135.85 & 16.05 \\
\hline
\end{tabular}

precipitation trends are strongest over the Upper Indus Punjab and Balochistan (table 4.2), and weaker over the Western Highlands and Coastal Belt. These historical patterns and trends in temperature and precipitation indicate some of the concerns that are arising in Pakistan over increased hydroclimatic risks.

Data from nine river stations (1961-2010) that contribute to the Indus Basin were analyzed: Indus, Chenab, Jhelum, Kabul, Swat, Ravi, Sutlej, Soan, and Harro. Table 4.3 shows the summary statistics; histograms of these flow records are shown in figures 4.3 and 4.4. The Indus mainstream flow varies from 45 to 80 million acre-feet (MAF), and for the Chenab and Jhelum, flow varies from 15 to 35 MAF. The Kabul River, the major surface water supply for North-West Frontier Province (NWFP), has inflow variations from 10 to 30 MAF. All other rivers show annual inflow values less than 10 MAF. Note that the flows from the Ravi and Sutlej (which originate in India) are governed by the Indus Water Treaty with India. Figure 4.5 shows the frequency analysis of these nine tributaries. The total 10 percent exceedance probability for all rivers is $210 \mathrm{MAF}$ and the total 90 percent exceedance probability is 101 MAF. These rivers also show a strong seasonal behavior with most of the flow dominating during the June-September months (figure 4.6). 
The time series of the Indus, Chenab, and Jhelum rivers demonstrates the relative stability of these rivers. A simple comparison of the coefficient of variation (CV) of the inter-annual flow of the Indus River with other major rivers in the world (table 4.4) shows the Indus at the lower end: the CV of the Indus is 13 percent, significantly lower than the world average of 49 percent. In comparison, the Ganges, which like the Indus arises from headwaters in the Himalaya, has almost twice the variability, with a CV of 27 percent. This is in

\section{Figure 4.3 Histogram of Annual Indus Inflow}

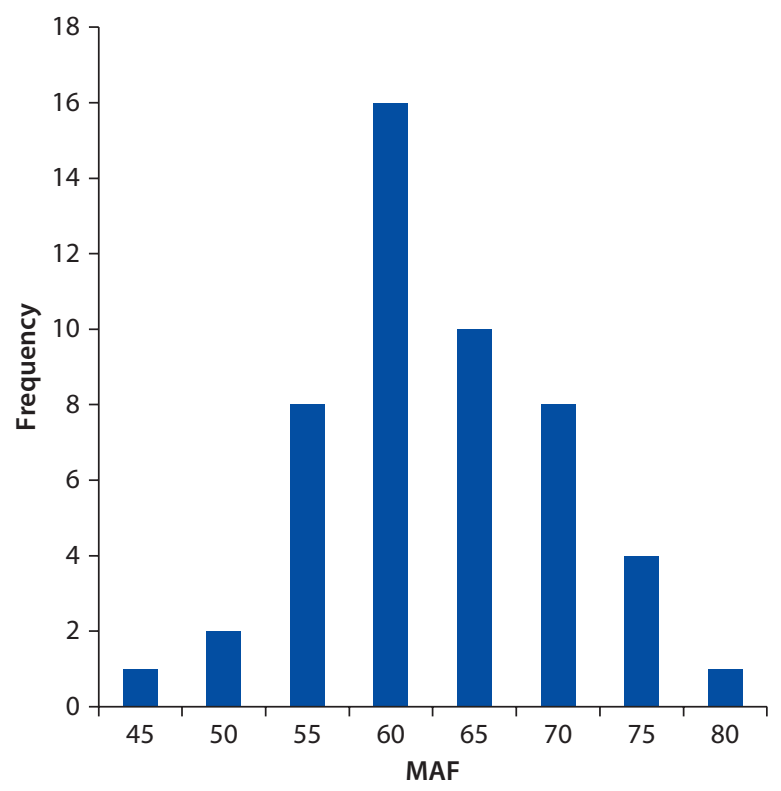

Note: MAF = million acre-feet.

Figure 4.4 Histogram of Annual Chenab, Jhelum, Kabul, Ravi, Sutlej, Swat, Soan, and Harro Inflows
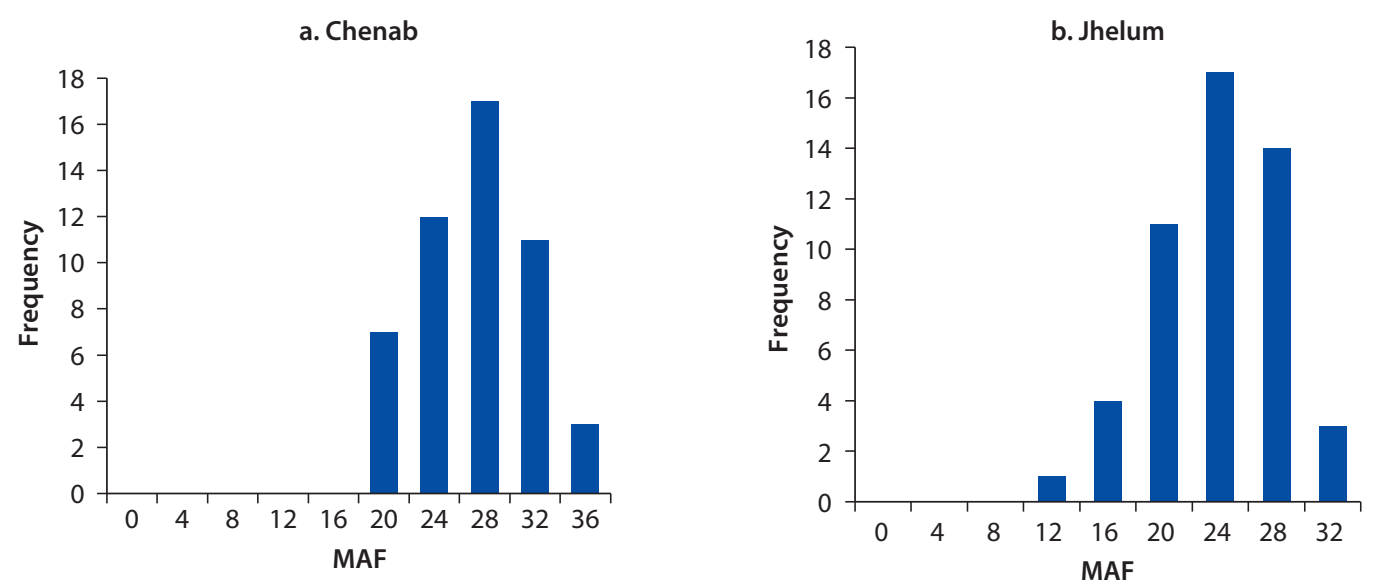

figure continues next page 
Figure 4.4 Histogram of Annual Chenab, Jhelum, Kabul, Ravi, Sutlej, Swat, Soan, and Harro Inflows (continued)
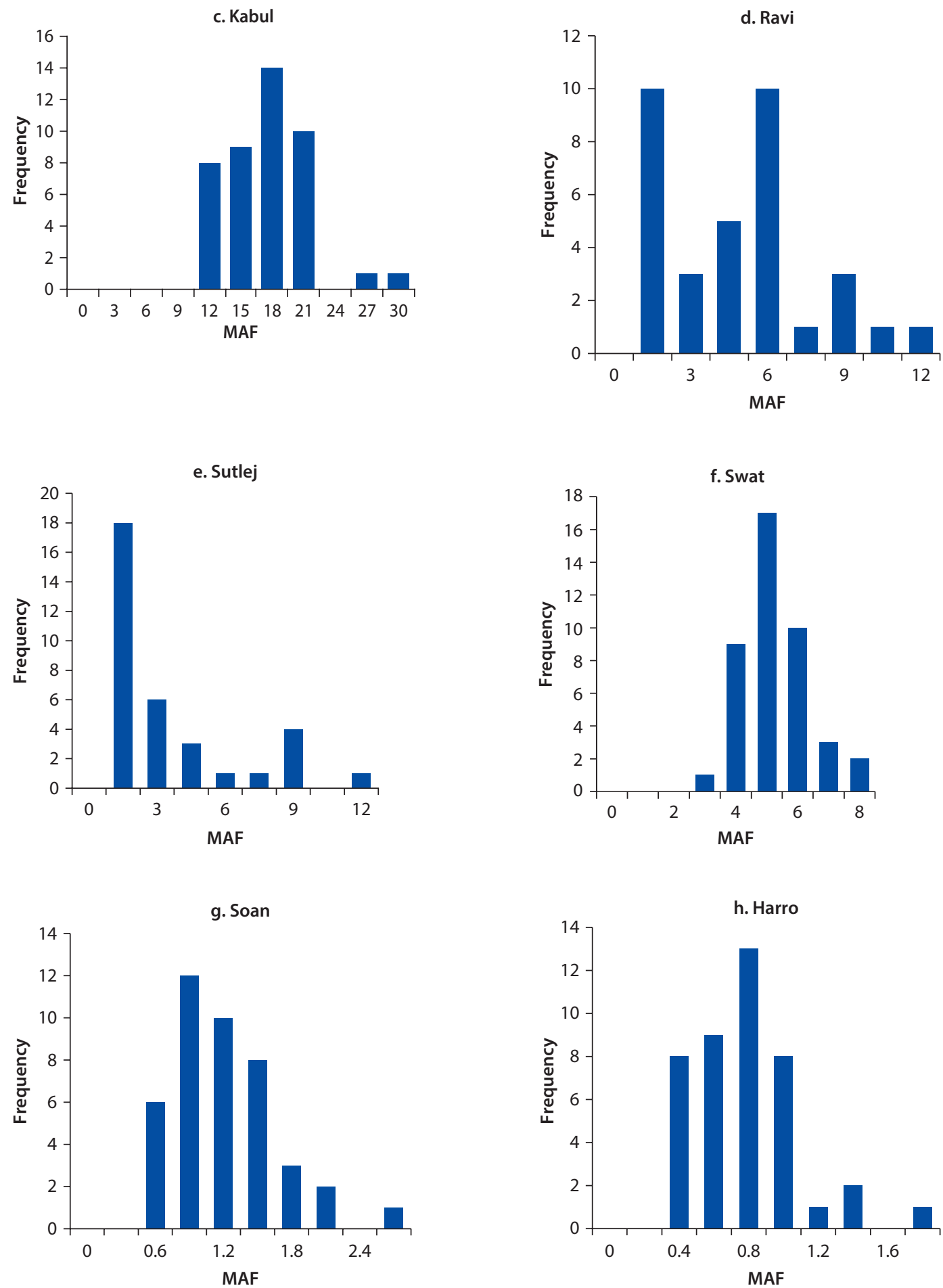

Note: MAF = million acre-feet. 
Figure 4.5 Frequency Analysis of Major Tributaries in the Indus Basin
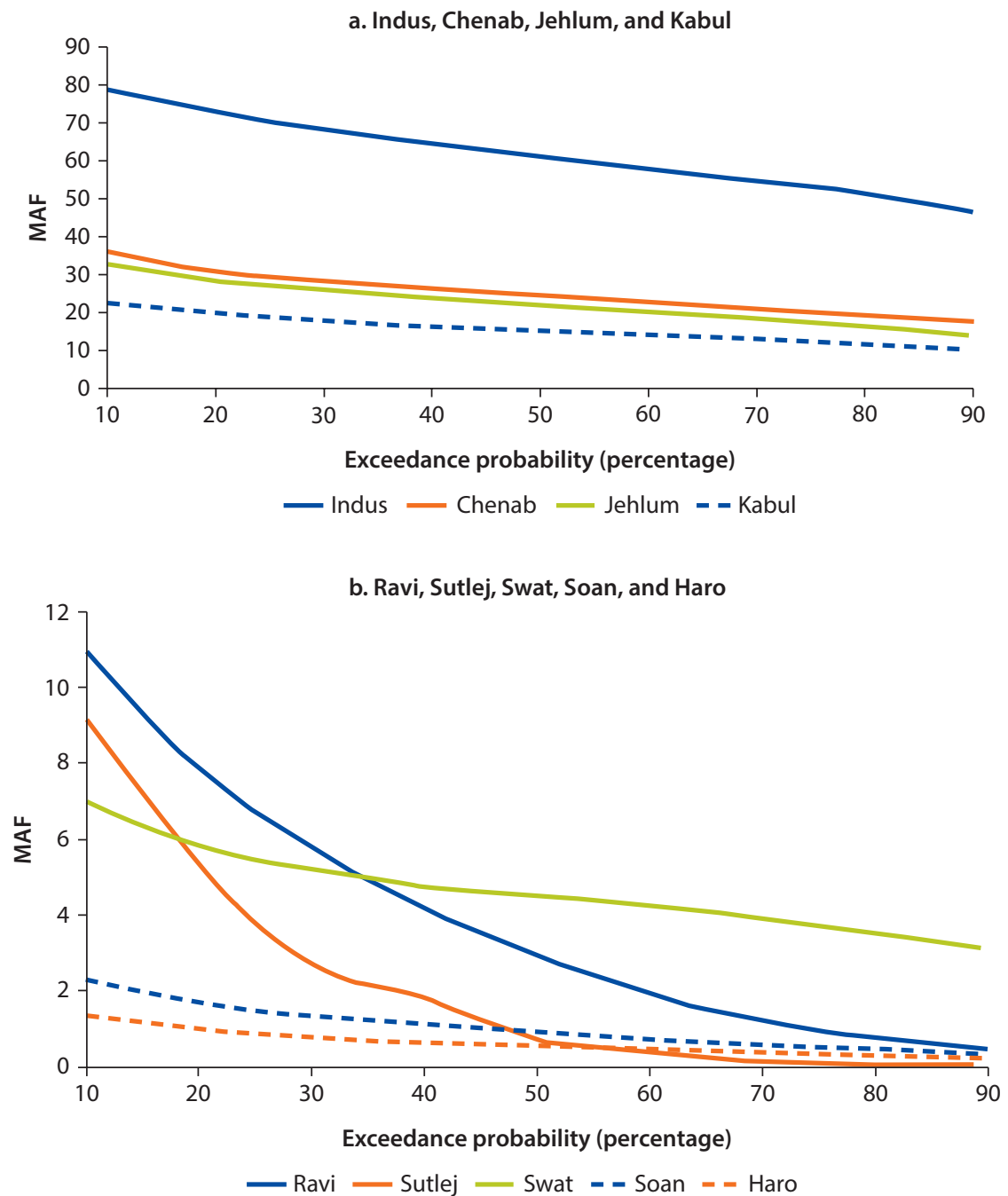

Note: MAF = million acre-feet.

part due to the moderating impact that snow and ice play in the headwaters of the system (as described in chapter 3). However, the impact of climate change on flow variability is still unknown for this region.

Annual historical inflows on the Indus have been declining (significant at 95 percent) over the period of record (figure 4.7). This is contrary to the general idea that an upward trend in discharge would be associated with increasing temperature (figure 4.1), precipitation (figure 4.2) and anticipated increasing melt waters (as discussed in Archer et al. 2010).

Intra-annually, there is some evidence that suggests a slight shift in the hydrograph toward earlier melting and inflows into the Indus. The data show that 21.7 percent of the total distribution flows into Tarbela were in June 
Figure 4.6 Average Monthly Inflow in IBMR from Nine Tributaries

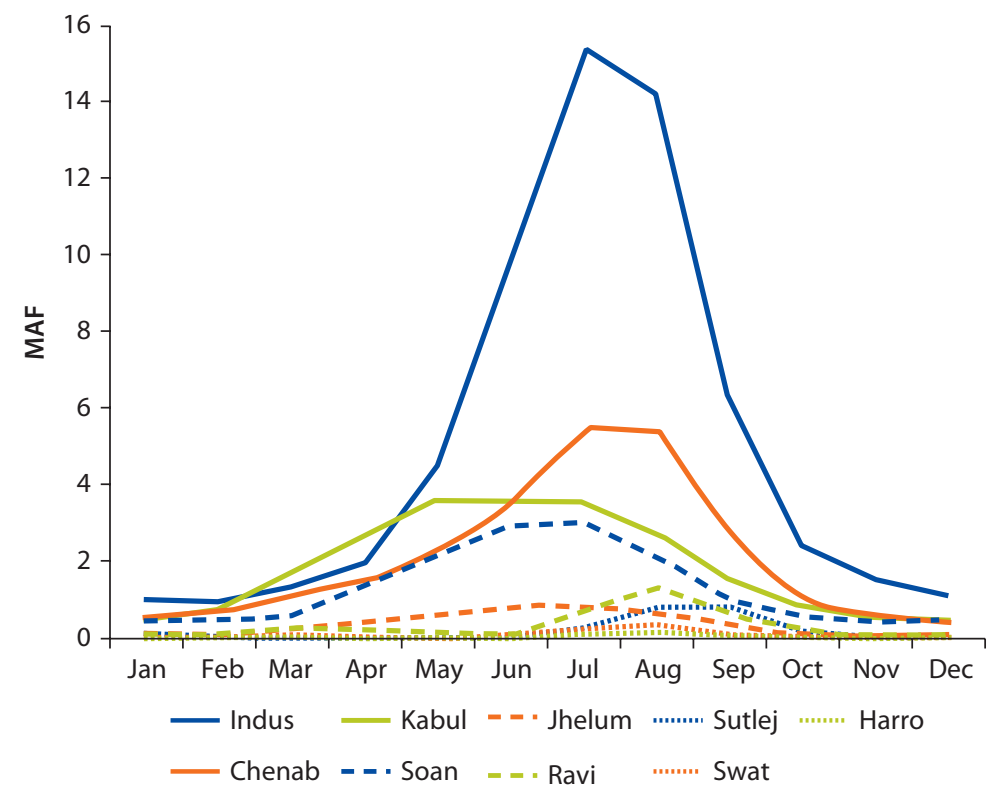

Note: MAF = million acre-feet.

Table 4.4 Coefficient of Variation for Major World Rivers

\begin{tabular}{lcl}
\hline River & CV (percentage) & \multicolumn{1}{c}{ Source } \\
\hline Indus & 13.0 & This study \\
Amazon & 27.0 & Villar et al. 2009 \\
Congo & 0.3 & Global Runoff Data Centre (GRDC) \\
Ganges & 27.0 & Mirza et al. 2001 \\
Murray-Darling & 60.0 & Simpson et al. 1993 \\
Mississippi & 21.0 & GRDC \\
Orinoco & 14.0 & Marengo 1995 \\
Yellow & 26.0 & Miao and Ni 2009 \\
World average & 49.0 & Dettinger and Diaz 2000
\end{tabular}

during the most recent decade in comparison to the earlier period of 40 years, in which only 18 percent of the total flows were in June. Moreover, the Chenab shows a slight increasing trend over time during the rabi period, October to March, (statistically significant at 95 percent) and the Indus shows a slightly decreasing trend over time during the kharif period, April to September (figure 4.8). An examination of monthly trends showed no clear trends except for a slight positive trend in May on the Chenab and a slight decrease in June on the Jhelum. These types of shifts will be tested in the model runs in later chapters. 
Figure 4.7 Indus Inflows, 1937-2011

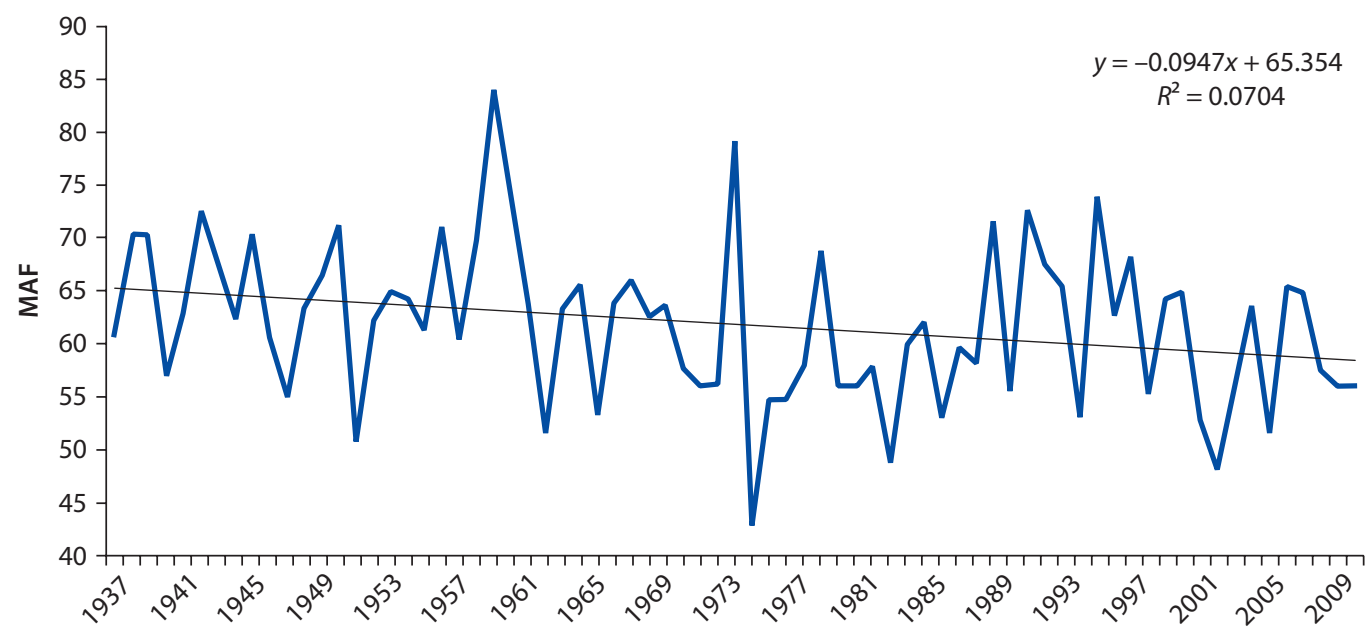

Note: $\mathrm{MAF}=$ million acre-feet

Figure 4.8 Time Series of Flows on the Indus, Jhelum, and Chenab, 1922-2009

a. Flows during rabi season
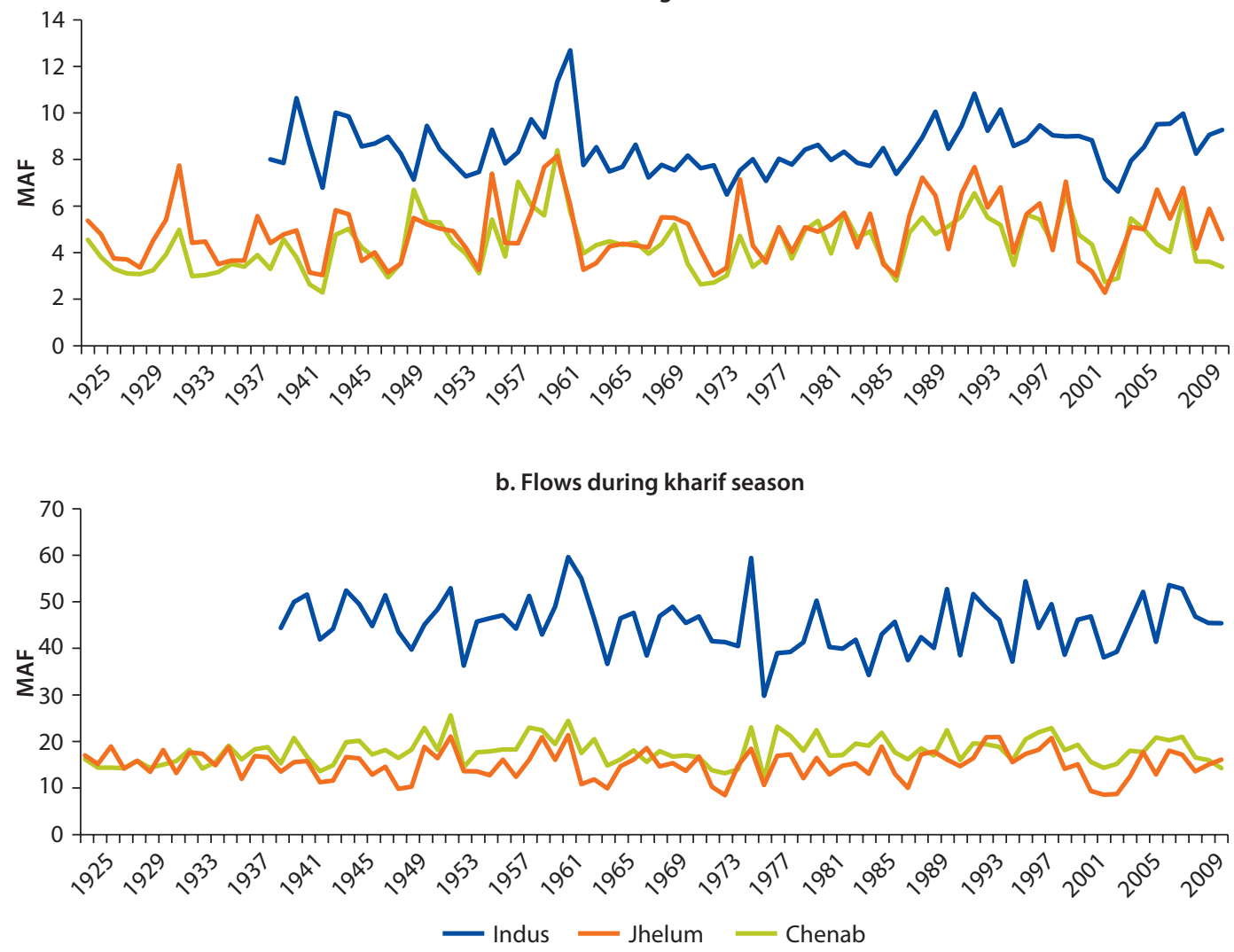

Note: MAF = million acre-feet. 


\section{Future Climate Change Risks}

The UIB and Indus Basin Irrigation System (IBIS) require different approaches to construct climate scenarios and develop the models undertaken in this report. The climates of the two areas are fundamentally different and the geographic scope of the subsequent models is limited to the IBIS region. The UIB has complex terrain and a precipitation regime dominated by westerly waves that generate winter snowfall. By comparison, the IBIS is a summer monsoondominated, gently sloping, highly constructed basin that begins below the rim stations. The GCISC analysis of climate change scenarios involves GCM outputs on a 1.0 degree grid, which also enabled comparison between GCM baseline runs and with CRU historical climate patterns. ${ }^{1}$ GCMs have been used to project scenarios of climate change under different trajectories of economic development and greenhouse gas emissions.

The GCISC-RR-03 research report (Islam et al. 2009b) drew upon the work of the IPCC (Intergovernmental Panel on Climate Change) Fourth Assessment Report (AR4) (IPCC 2007), completed in 2007. GCISC took this opportunity to analyze 17 new GCM model outputs for the AR4 scenarios, individually and in ensemble runs (17 and 13 models were used for the $\mathrm{A}_{1 \mathrm{~B}}$ ? and A2 emissions scenarios respectively. The A2 emissions scenario represents one of the higher emissions scenarios of the future. The GCISC included in the output the mean monthly temperature and precipitation projections for the 2020s, 2050s, and 2080s. Although the 2080 projections are used by climatologists, they are unrealistic as far accuracy of predictions of future water and agricultural systems. There is no credible way to anticipate linkages among these systems out to the 2080s, and even the 2050s are likely to have numerous unforeseen surprises. Only the GCMs that matched the historical normals (1961-90) well (here defined as less than $2^{\circ} \mathrm{C}$ difference and less than 20 percent difference in precipitation) were examined in the GCISC analysis.

\section{Future Climate in the Indus Basin Irrigation System}

These GCISC modeling results (figure 4.9) show that by the 2020s the temperature is expected to rise by about $2^{\circ} \mathrm{C}$ in northern Pakistan, $1.5^{\circ} \mathrm{C}$ in the central parts of the country, and $1{ }^{\circ} \mathrm{C}$ in the coastal areas. Temperatures will continue to increase into the 2050s and 2080s. As for precipitation, the changes in Pakistan are not conclusive, even out to 2080s. These impacts are even less for the A1B and B2 emissions scenarios. This highlights the difficulty in making both estimates of magnitude and direction for precipitation.

Focusing more on comparisons between the northern parts of Pakistan (that is, UIB) and the southern parts (that is, IBIS), simulations of 17 GCMs, the ensemble values (and standard errors) are shown in tables 4.5 and 4.6. For both the A2 and A1B scenarios, temperatures are likely to be near $4{ }^{\circ} \mathrm{C}$ warmer 
by 2080. Moreover, under these GCISC model runs, it is difficult to say with certainty how precipitation will change, because the uncertainties are large in all cases.

Moreover, it is important to consider seasonal changes as well (tables 4.7 and 4.8). In the northern region this means focusing on winter precipitation. In most GCM projections, winter temperatures increase only slightly more than summer temperatures. Seasonal precipitation differences are significant, but they vary so much in sign and magnitude as to defy generalization across GCM models, and we therefore concentrate on sensitivity analysis (chapter 6) (Islam et al. 2009a, 2009b, 2009c). In light of these seasonal results, the study team did not analyze more disaggregated GCM monthly output.

\section{Figure 4.9 Ensemble Change of Temperature and Precipitation for the A2 Scenario}

a. Mean annual ensemble change of temperature $\left({ }^{\circ} \mathrm{C}\right)$
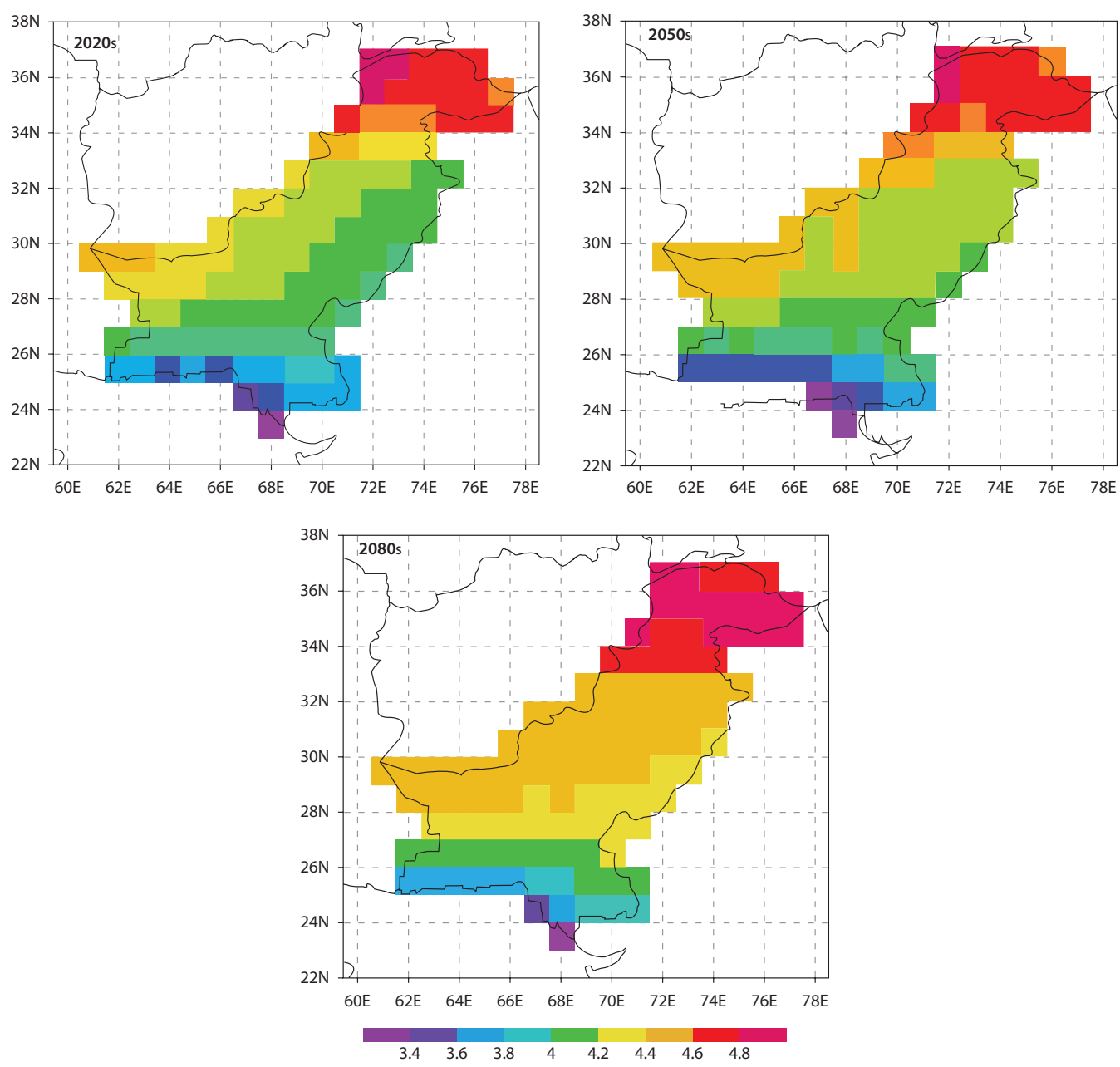

figure continues next page 
Figure 4.9 Ensemble Change of Temperature and Precipitation for the A2 Scenario (continued)

b. Mean annual ensemble change of precipitation (percentage)
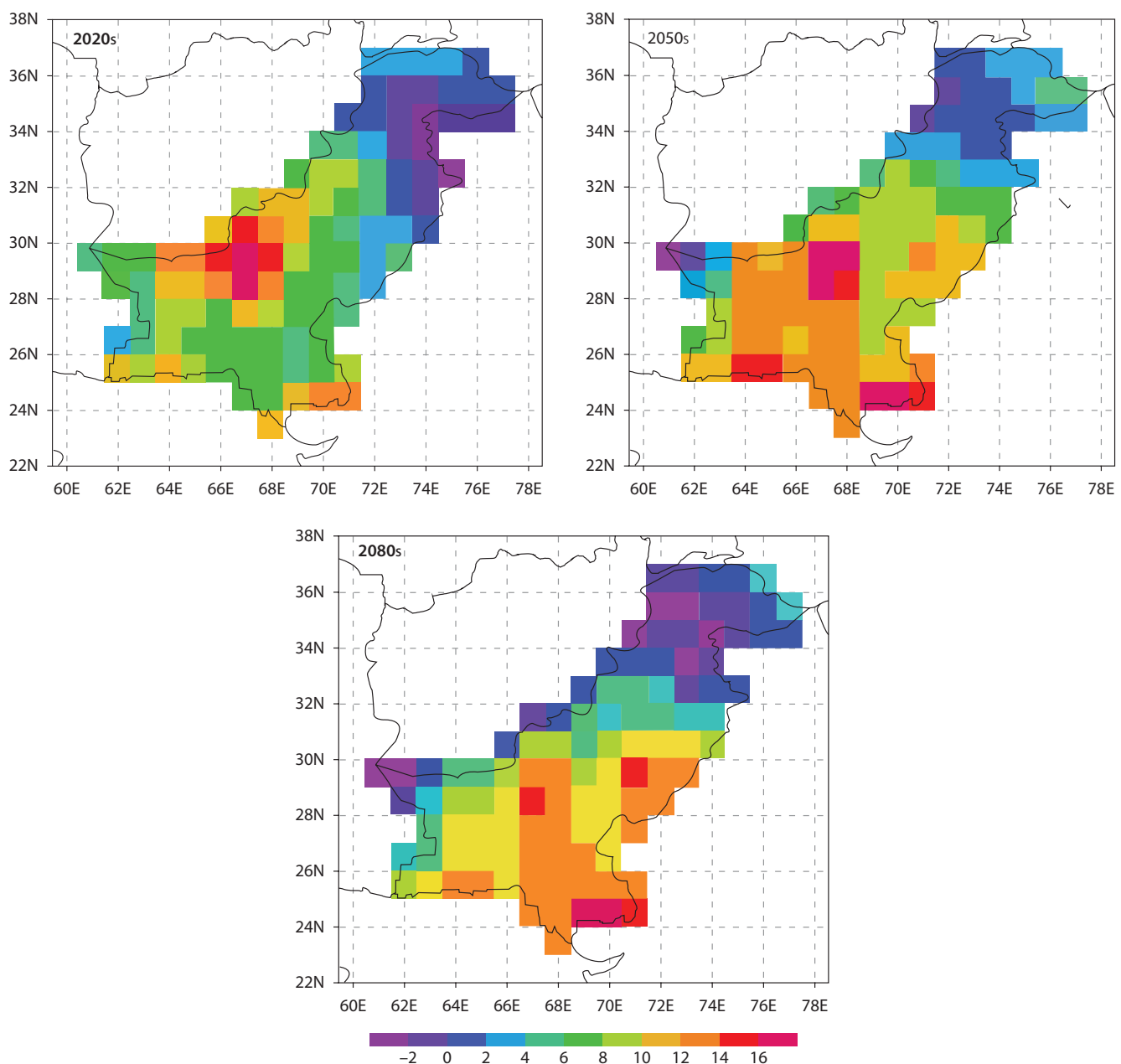

Source: $\odot$ Global Change Impact Study Centre. Reproduced, with permission, from Islam et al. 2009b; further permission required for reuse.

Table 4.5 Ensemble Mean of Climate Change Projections Based on IPCC-AR4 Using 17 GCMs and the A2 Special Report on Emissions Scenarios

\begin{tabular}{lccr}
\hline Area & $2020 \mathrm{~s}$ & $2050 \mathrm{~s}$ & $2080 \mathrm{~s}$ \\
\hline & & Temperature change $\left({ }^{\circ} \mathrm{C}\right)$ & \\
Northern Pakistan & $1.4 \pm 0.1$ & $2.7 \pm 0.2$ & $4.7 \pm 0.2$ \\
Southern Pakistan & $1.3 \pm 0.1$ & $2.4 \pm 0.1$ & $4.2 \pm 0.2$ \\
& & Precipitation change (\%) & $1.1 \pm 4.0$ \\
Northern Pakistan & $2.2 \pm 2.3$ & $3.6 \pm 3.2$ & $4.3 \pm 9.4$ \\
Southern Pakistan & $3.1 \pm 5.1$ & $6.4 \pm 7.5$ & 4.4 \\
\hline
\end{tabular}

Source: GCISC.

Note: IPCC-AR4 = Intergovernmental Panel on Climate Change Fourth Assessment Report, GCM = general circulation model. 
Table 4.6 Ensemble Mean of Climate Change Projections Based on IPCC-AR4 Using 17 GCMs and the A1B Special Report on Emissions Scenarios

\begin{tabular}{lccc}
\hline Area & $2020 \mathrm{~s}$ & $2050 \mathrm{~s}$ & $2080 \mathrm{~s}$ \\
\hline & & Temperature change $\left({ }^{\circ} \mathrm{C}\right)$ & \\
Northern Pakistan & $1.6 \pm 0.1$ & $3.0 \pm 0.2$ & $4.1 \pm 0.2$ \\
Southern Pakistan & $1.4 \pm 0.1$ & $2.6 \pm 0.1$ & $3.7 \pm 0.2$ \\
& & Precipitation change (\%) & \\
Northern Pakistan & $-0.7 \pm 1.5$ & $-1.8 \pm 2.2$ & $-0.7 \pm 3.1$ \\
Southern Pakistan & $-3.2 \pm 4.3$ & $-0.3 \pm 5.5$ & $-0.9 \pm 7.9$ \\
\hline
\end{tabular}

Source: GCISC.

Note: IPCC-AR4 = Intergovernmental Panel on Climate Change Fourth Assessment Report, GCM = general circulation model.

Table 4.7 Projected Summer (JJAS) Changes Using 17 GCMs

\begin{tabular}{|c|c|c|c|c|}
\hline \multirow[b]{2}{*}{ Scenario/area } & \multicolumn{2}{|c|}{$A 2$} & \multicolumn{2}{|c|}{$A 1 B$} \\
\hline & $2020 s$ & $2050 \mathrm{~s}$ & $2020 s$ & $2050 \mathrm{~s}$ \\
\hline & \multicolumn{4}{|c|}{ Temperature change $\left({ }^{\circ} \mathrm{C}\right)$} \\
\hline Northern Pakistan & $1.3 \pm 0.1$ & $2.6 \pm 0.2$ & $1.5 \pm 0.1$ & $2.9 \pm 0.2$ \\
\hline \multirow[t]{2}{*}{ Southern Pakistan } & $1.1 \pm 0.1$ & $2.2 \pm 0.2$ & $1.2 \pm 0.1$ & $2.4 \pm 0.2$ \\
\hline & \multicolumn{4}{|c|}{ Precipitation change (\%) } \\
\hline Northern Pakistan & $5.5 \pm 3.7$ & $7.6 \pm 6.5$ & $1.3 \pm 3.0$ & $1.8 \pm 4.7$ \\
\hline Southern Pakistan & $12.5 \pm 9.8$ & $42.2 \pm 27.0$ & $11.2 \pm 11.0$ & $24.1 \pm 18.1$ \\
\hline
\end{tabular}

Source: GCISC.

Note: JJAS = June, July, August, and September, GCM = general circulation model.

Table 4.8 Projected Winter (ONDJ) Changes Using 17 GCMs

\begin{tabular}{lcccc}
\hline & \multicolumn{3}{c}{$A 2$} & \multicolumn{2}{c}{ A1B } \\
\cline { 2 - 3 } Scenario/area & $2020 \mathrm{~s}$ & $2050 \mathrm{~s}$ & $2020 \mathrm{~s}$ & $2050 \mathrm{~s}$ \\
\hline \multirow{3}{*}{ Northern Pakistan } & $1.5 \pm 0.1$ & Temperature change $\left({ }^{\circ} \mathrm{C}\right)$ \\
Southern Pakistan & $1.4 \pm 0.1$ & $2.8 \pm 0.2$ & $1.7 \pm 0.1$ & $3.0 \pm 0.2$ \\
& & $2.6 \pm 0.1$ & $1.6 \pm 0.1$ & $2.8 \pm 0.1$ \\
Northern Pakistan & $-0.7 \pm 2.3$ & Precipitation change (\%) & \\
Southern Pakistan & $-7.5 \pm 6.1$ & $0.7 \pm 3.2$ & $-2.6 \pm 1.9$ & $-4.7 \pm 2.6$ \\
\hline
\end{tabular}

Source: GCISC.

Note: ONDJ = October, November, December, and January, GCM = general circulation model.

The temperature increases in both summer and winter are higher in northern Pakistan than in southern Pakistan. Moreover, temperature increases tend to be on average higher during the winter than the summer. General trends are more difficult to surmise with precipitation because the standard errors are large. There is some indication, however, of a general trend in increased precipitation during the summer and a decrease during the winter. The changes appear to be more pronounced in the southern parts of the country. 


\section{Future Climate in the Upper Indus Basin}

Though debate is ongoing as to the scientific soundness of using GCMs to make predictions in high topography areas, the GCISC-RR-03 report (Islam et al. 2009b.) provides predicted changes in temperature and precipitation in the UIB (table 4.9).

There is agreement among models regarding increases in temperature. But, the direction of precipitation is unclear because the standard errors are large. Moreover, a key question is how these changes might affect river discharge and inflows into the Indus Basin. Using the UIB model developed in chapter 3 and assuming a much larger change than is being predicted by the 17 GCMs above, scenarios can be generated of different inflows into the Tarbela Dam on the Indus main stem (table 4.10).

These future projections indicate that the simple physical ablation model yields inflows into the Indus main stem ranging from 45.4 to $73.8 \mathrm{MAF}$, or from 78 to 126 percent of the mean historical discharge of the Indus at Tarbela.

\begin{tabular}{|c|c|c|c|}
\hline & $2020 s$ & $2050 s$ & $2080 \mathrm{~s}$ \\
\hline & \multicolumn{3}{|c|}{ A2 Scenario } \\
\hline Temperature changes & $1.48 \pm 0.12$ & $2.84 \pm 0.17$ & $4.84 \pm 0.24$ \\
\hline \multirow[t]{2}{*}{ Precipitation changes } & $0.60 \pm 1.55$ & $2.47 \pm 1.82$ & $1.84 \pm 2.36$ \\
\hline & \multicolumn{3}{|c|}{ A1B } \\
\hline Temperature changes & $1.63 \pm 0.11$ & $3.10 \pm 0.21$ & $4.36 \pm 0.31$ \\
\hline Precipitation changes & $-0.15 \pm 1.04$ & $0.28 \pm 1.60$ & $2.08 \pm 2.26$ \\
\hline
\end{tabular}

Source: GCISC.

Table 4.10 First-Order Effects of Temperature and Precipitation Changes on Discharge into the Indus Main Stem

\begin{tabular}{llllll}
\hline Temperature changes $\left({ }^{\circ} \mathrm{C}\right)$ & \multicolumn{5}{c}{ Precipitation changes, MAF (percentage of baseline) } \\
\hline & $-20 \%$ & $-10 \%$ & No change & $+10 \%$ & $+20 \%$ \\
+0.5 & $45.4(78)$ & $50.3(86)$ & $55.1(94)$ & $60(103)$ & $64.9(111)$ \\
+1.5 & $46.2(79)$ & $51.1(88)$ & $55.9(96)$ & $60.8(104)$ & $65.7(113)$ \\
+2.0 & $46.2(79)$ & $51.1(88)$ & $55.9(96)$ & $60.8(104)$ & $65.7(113)$ \\
+3.0 & $48.6(83)$ & $53.5(92)$ & $58.4(100)$ & $63.2(108)$ & $68.1(117)$ \\
+4.0 & $52.7(90)$ & $57.6(99)$ & $62.4(107)$ & $67.3(115)$ & $72.2(124)$ \\
+4.5 & $54.3(93)$ & $59.2(101)$ & $64(110)$ & $68.9(118)$ & $73.8(126)$ \\
\hline
\end{tabular}

Note: Baseline temperature and precipitation gives an average of 48.7 million acre-feet (MAF) of snowmelt and 9.7 MAF of ice melt, for a total baseline of 58.4 MAF. Percentage change in precipitation is assumed to be directly proportional to changes in snowmelt contributions to runoff. For increases in T, the ablation gradient concept was used, as described in chapter 3 . As the temperature increases, the firn line moves upward on the glacier, producing an increase in the surface area of the ablating portion of the glacier (the "ablation facies"). For example, for a 0.5 degree increase in temperature and a 10 percent increase precipitation, it is calculated that the snowmelt contribution would increase to $53.5 \mathrm{MAF}$ and, based on the earlier analysis, the ice melt contribution would decrease to 6.5 MAF. However, the total runoff would increase to 60 MAF (103 percent above the baseline). 
Figure 4.10 Future Indus Inflow Histogram Using the UIB Model

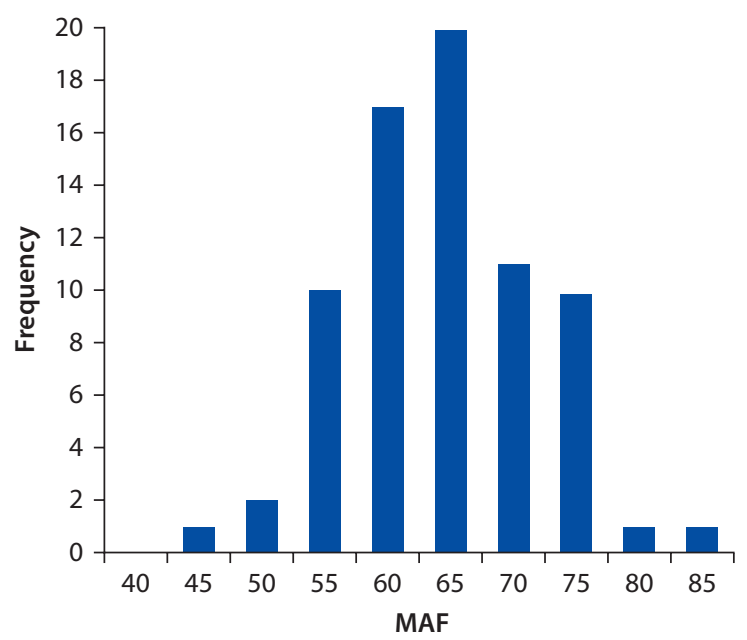

Note: $\mathrm{MAF}=$ million acre-feet, $\mathrm{UIB}=$ Upper Indus Basin.

Interestingly, the histogram of melt water estimates (figure 4.10) are quite similar to the historical discharge volumes (see figure 4.3, page 81 ).

Thus, based on the analyses of this study, it is estimated that the present inter-annual variations in stream flow from the tributaries of the UIB are generally comparable to the postulated impacts of the climate change scenarios currently being applied to the mountains of South Asia. So it can be concluded that the primary impact of all but the most extreme climate change scenarios will be a shift in the timing of peak runoff, and not a major change in annual volume.

\section{Notes}

1. Each of the GCM models analyzed uses a different grid. GCM grid sizes range from $2.8 \times 2.8$ to $5.6 \times 5.6$ degrees (GCISC-RR-02 [Faisal et al. 2009] and RR-04 [Saeed, Sheikh, and Khan 2009d, 4]). GCISC worked with the University of Trieste to interpolate model output values for all grid cells onto the same 0.5 -degree grid to compare the baseline runs.

2. The Al scenario family describes a future world of very rapid economic growth, global population that peaks in mid-century and declines thereafter, and the rapid introduction of new and more efficient technologies. The AlB scenario is a "balance" scenario across all sources. Where balanced is defined as not relying too heavily on one particular energy source, on the assumption that similar improvement rates apply to all energy supply and end-use technologies. The A2 scenario family describes a very heterogeneous world. The underlying theme is self-reliance and preservation of local identities. Fertility patterns across regions converge very slowly, which results in continuously increasing population. 


\section{References}

Ali, G., S. Hasson, and A. M. Khan. 2009. Climate Change: Implications and Adaptation of Water Resources in Pakistan. Research Report GCISC-RR-13, Global Change Impact Study Centre, Islamabad.

Archer, D. R., N. Forsythe, H. J. Fowler, and S. M. Shah. 2010. "Sustainability of Water Resources Management in the Indus Basin under Changing Climatic and Socio Economic Conditions." Hydrology and Earth System Sciences 14: 1669-80.

Dettinger, M. D. and H. F. Diaz. 2000. "Global Characteristics of Stream Flow Seasonality and Variability." Journal of Hydrometeorology 1: 289-310.

Faisal, S., S. Syed, S. Islam, N. Rehman, M. M. Sheikh, and A. M. Khan. 2009. Climate Change Scenarios for Pakistan and Some South Asian Countries for SRES A2 and B2 Scenarios Based on Six Different GCMs Used in IPCC-TAR. Research Report GCISC-RR-02, Global Change Impact Studies Centre, Islamabad.

IPCC (Intergovernmental Panel on Climate Change). 2007. Synthesis Report: Contribution of Working Groups I, II and III to the Fourth Assessment Report of the Intergovernmental Panel on Climate Change, edited by R. K. Pachauri and A. Reisinger. IPCC, Geneva, Switzerland.

Iqbal, M. M., M. A. Goheer, S. A. Noor, H. Sultana, K. M. Salik, and A. M. Khan. 2009a. Climate Change and Agriculture in Pakistan: Adaptation Strategies to Cope with Negative Impacts. Research Report GCISC-RR-16, Global Change Impact Studies Centre, Islamabad.

2009b. Climate Change and Rice Production in Pakistan: Calibration, Validation and Application of CERES-Rice Model. Research Report GCISC-RR-15, Global Change Impact Studies Centre, Islamabad.

- 2009c. Climate Change and Wheat Production in Pakistan: Calibration, Validation and Application of CERES-Wheat Model. Research Report GCISC-RR-14, Global Change Impact Studies Centre, Islamabad.

Islam, S., N. Rehman, M. M. Sheikh, and A. M. Khan. 2009a. Assessment of Future Changes in Temperature Related Extreme Indices over Pakistan Using Regional Climate Model PRECIS. Research Report GCISC-RR-05, Global Change Impact Study Centre, Islamabad.

2009b. Climate Change Projections for Pakistan, Nepal and Bangladesh for SRES A2 and A1B Scenarios Using Outputs of 17 GCMs Used in IPCC-AR4. Research Report GCISC-RR-03, Global Change Impact Study Centre, Islamabad.

- 2009c. High Resolution Climate Change Scenarios over South Asia Region Downscaled by Regional Climate Model PRECIS for IPCC SRES A2 Scenario. Research Report GCISC-RR-06, Global Change Impact Study Centre, Islamabad.

Marengo, J. A. 1995. "Variations and Change in South American Streamflow." Climatic Change 31, 99-117.

Miao, C. Y., and J. R. Ni. 2009. "Variation of Natural Streamflow since 1470 in the Middle Yellow River, China." International Journal of Environmental Research and Public Health 6: 2849-64.

Mirza, M. M. Q., R. A. Warrick, N. J. Ericksen, and G. J. Kenny. 2001. "Are Floods Getting Worse in the Ganges, Brahmaputra and Meghna Basins?" Environmental Hazards 3 (2): 37-48. 
Saeed, F., M. R. Anis, R. Aslam, and A. M. Khan. 2009a. Comparison of Different Interpolation Methods for Temperature Mapping in Pakistan. Research Report GCISC-RR-10, Global Change Impact Study Centre, Islamabad.

- 2009b. Development of Climate Change Scenarios for Specific Sites Corresponding to Selected GCM Outputs, Using Statistical Downscaling Techniques. Research Report GCISC-RR-09, Global Change Impact Study Centre, Islamabad.

Saeed, F., S. Jehangir, M. Noaman-ul-Haq, W. Shafeeq, M. Z. Rashmi, G. Ali, and A. M. Khan. 2009c. Application of UBC and DHSVM Models for Selected Catchments of Indus Basin Pakistan. Research Report GCISC-RR-11, Global Change Impact Study Centre, Islamabad.

Saeed, S., M. M. Sheikh, and A. M. Khan. 2009d. Validation of Regional Climate Model PRECIS over South Asia. Research Report GCISC-RR-04, Global Change Impact Study Centre, Islamabad.

Sheikh, M. M., N. Manzoor, M. Adnan, J. Ashraf, and A. M. Khan. 2009. Climate Profile and Past Climate Changes in Pakistan. Research Report GCISC-RR-01, Global Change Impact Study Centre, Islamabad.

Simpson, H. J., M. A. Cane, A. L. Herczeg, S. E. Zebiak, and J. H. Simpson. 1993. "Annual River Discharge in Southeastern Australia Related to El Nino-Southern Oscillation Forecasts of Sea Surface Temperature." Water Resources Research 29 (11): 3671-80.

Syed, F. S., S. Mehmood, M. A. Abid, M. M. Sheikh, and A. M. Khan. 2009. Validation of the Regional Climate Model RegCM3 over South Asia. Research Report GCISC-RR-07, Global Change Impact Study Centre, Islamabad.

Villar, J. C. E., J. L. Guyot, J. Ronchail, G. Cochonneau, N. Filizola, P. Fraizy, D. Labat, E. de Oliveira, J. J. Ordonez, and P. Vauchel. 2009. "Contrasting Regional Discharge Evolutions in the Amazon Basin (1974-2004)." Journal of Hydrology 375 (3-4): 297-311.

Wescoat, J., and R. Leichenko. 1992. "Complex River Basin Management in a Changing Global Climate: Indus River Basin Case Study in Pakistan-A National Modeling Assessment." Collaborative Paper 5, Center for Advanced Decision Support for Water and Environmental Systems, and Civil, Environmental, and Architectural Engineering, University of Colorado, Boulder, CO. 
